\title{
Joan la Pucelle and the Inverted Saints Play in 1 Henry VI
}

\section{ALBERT H. TRICOMI}

Résumé : Henri VI, Première Partie, est une pièce de théâtre profondément impliquée dans le projet réformateur de différencier l'idolâtrie de la dévotion religieuse authentique. Au moyen de sa représentation de Joan la Pucelle, supposée faiseuse de miracles et virtuelle sainte révélée comme sorcière, la pièce rappelle de façon parodique, donc sans risque, certains éléments des pièces sur les saints déjà supprimées. De même, les Acts and Monuments de Foxe, ouvrage très populaire, fournissait au public élisabéthain un modèle de comportement des martyrs véritables de l'Église Réformée.

$\mathrm{O}$ ver the last decade or so, scholars of the early-modern period have become immersed in a productive debate on the ideological relationship between Elizabethan theater and ecclesiastical authority. Louis Montrose argues that although "many traces" of the old ecclesiastical cycle drama remained in England after 1580, the Elizabethan regime, carrying forward the burden of the Reformation, succeeded in substituting the "spectacles of royal and civic power" for "most of the ritual practices and popular religious festivities of late medieval Catholic culture."1 Drawing upon Steven Mullaney's view that London's theaters, geographically located at the margins of the city, were able to produce a drama of challenging ideas and debate, Montrose takes a strong polemical position: "I want to disassociate my own secularist perspective on sociocultural change," he states, "from [Michael] O'Connell's recuperation of the Shakespearean theatre for an aesthetic of late medieval Catholic spirituality." 2 Montrose cites O'Connell's article, "The Idolatrous Eye," in order to dispute the latter's contention that the "nascent public theaters," although "formally secular," were deeply concerned with issues of idolatry and iconoclasm, not only because the theaters were vulnerable to attack, but because they were the products of an altered 
Reformation sensibility. ${ }^{3}$ O'Connell's view that the Elizabethan theater was imbued with a powerful, Reform-inspired anti-theatricality has since been expressed comprehensively in Huston Diehl's argument that the meta-theatricality of Elizabethan theater was impelled by the Reformation's profound distrust of incarnational and idolatrous ways of seeing. ${ }^{4}$

In responding to these divergent claims, I propose to raise the particular case of the English history play, 1 Henry VI, with its extensive depiction of Joan of Arc, or Joan la Pucelle. My focus is the speech by France's Dauphin Charles, who, having fallen under Joan's spell, lauds her in these words:

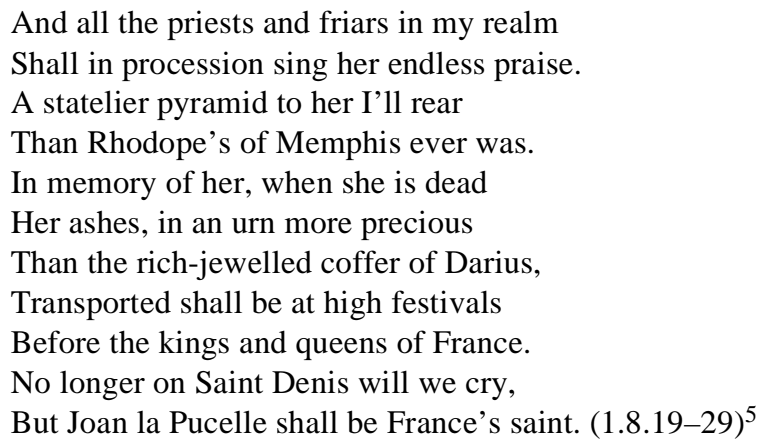

The question I would like to address is whether this speech is primarily incidental to the depiction of Joan, exhibiting, as Montrose would say, no more than one of the "many traces" of the older ecclesiastical drama, given that the play functions as the product of a secular theater. If the old religious drama with its representations of saints was so completely suppressed, why is it that Charles's speech spectacularly recollects old-faith practices of ceremonial procession, replete with a popish train of ecclesiastics, cultish worship at a shrine, and the envisioning of a new holiday in honor of the "saint" - the affective word toward which the entire passage builds? ${ }^{6}$

Not only this passage, but the entire representation of Joan la Pucelle is, in my view, intensely engaged in the Reformation project of differentiating idolatry from genuine religious worship. It also seeks to distinguish true sainthood and martyrdom from deceptive appearances of the same. In my view the play's representation of Joan absorbs and responds to features of the iconoclastic attacks propagated by Protestant reformers on the idolatrous worship of saintly images and icons. Moreover, for Elizabethan audiences, the distinctive re-enactment of Joan's burning in 1 Henry VI must have been seen, at least in part, through the lens provided by John Foxe's Acts and Monuments, commonly known as "The Book of Martyrs," the monumental work that unforgettably furnished the English nation with a pantheon of martyrs whose exemplary behavior, usually at the stake, defined the hall- 
marks of the true saints, as it were, of the new Reformed Church. Even more emphatically, 1 Henry VI re-enacts from the safe distance of parody features of the suppressed saints plays of the late medieval period. Through its extensive use of parody and irony, the play presents, I intend to show, hortatory examples of what the reformers called "reformed seeing." Nonetheless, from an audience-response perspective, the play depends upon, and thus cannot totally avert, responses of nostalgia or longing for an older manner of worship issuing from a positive identification with saints and saints' miracles.

My manner of approaching this complex subject bears a special relationship to feminist treatments of 1 Henry VI, of which we have had many in the last decade, for these have drawn attention to the protean, often contradictory, manner of Joan's representation. Their range has been remarkable. Gabriele Bernhard Jackson has examined the linkages between Joan as witch and virago and the iconographic traditions of the amazon and the warrior woman. ${ }^{7}$ Leah Marcus's "local reading," with its emphasis on audience response, has attributed topical associations to Joan as a cross-dressing warrior whose suitors, Alençon and Anjou, bear the same names as those who courted Elizabeth, England's military Queen, who appeared in manly armor at Tilbury in $1588 .{ }^{8}$ Following this parallel, Marcus discerns in "La Pucelle" a topical shadowing of Elizabeth, whose cult offered the populace a secularized displacement for the Virgin Mary. ${ }^{9}$ Others have called attention to Joan's ambiguous role as prophetess - either sibyl or siren-deceiver - and as a shepherd's daughter who is either virgin or whore ("Pucelle" or "Puzzel"). ${ }^{10}$ Still others have treated Joan's role as a Petrarchan mistress, or a classical amazon who nevertheless bears the biblical sword of Deborah. ${ }^{11}$ Coppélia Kahn gathers these multiple associations together, saying, "As virgin prophetess, mannish amazon, and seductive courtesan, Joan is a composite portrait of the ways women are dangerous to men."12

These gendered interpretations have principally depended upon topical political and cultural contexts, as well as secular Elizabethan history. ${ }^{13}$ Surprisingly, contemporary religious contexts in which Joan's prominent role as miracle worker and putative saint may be understood remain largely neglected. From a feminist standpoint, these religious contexts afford fresh perspectives from which to understand women's place in the old order and the new. By examining Joan La Pucelle in relation to the old-faith dramatic representations of female saints such as Mary Magdalene and the Virgin Mary, we can illuminate the play's relationship to the iconoclastic movement and the controversy over the idolatrous worship of sensuous, particularly female, images. Furthermore, by comparing the manner in which Joan 
faces her burning with that of Anne Askew, the preeminent female martyr in Foxe, we gain a powerful perspective in interpreting how many Elizabethans may have responded to Joan's punishment.

Through these contexts, then, I propose to treat 1 Henry VI as a secular play that nonetheless uses its representation of Joan La Pucelle to engage a highly charged Reformation subject. Since this approach advances the view that 1 Henry VI parodies the old-faith beliefs enacted in the earlier miracle or saints plays, it will be useful, procedurally, to review briefly the devolution of that miracle-play tradition as the playwright or playwrights (Shakespeare or Nashe, or both, perhaps with others) ${ }^{14}$ and audiences received it.

Although the Henrican Reformation doomed the civic Corpus Christi cycle plays and the miracle plays about the lives of the saints, these thriving genres were not officially prohibited until Elizabeth's proclamation of May $16,1559 .{ }^{15}$ Nonetheless the civic cycle plays persisted, usually with various sorts of censoring (especially the non-biblical subjects of the Virgin Mary's coronation, death, and assumption), into the 1570s and were not totally suppressed until 1580 - about a decade before the composition of 1 Henry $V I .{ }^{16}$ Related to the civic plays featuring the Virgin were the once-flourishing saints or miracle plays. Of these John Wasson reports that, despite our necessarily incomplete records, we know that "far more were saint plays than were Corpus Christi, morality, Christmas, Easter, or other mystery plays," and, moreover, that "[a]t least thirty-eight different saints had at least sixty-six different plays written about them." 17 Subgroups of these plays treated the saint's conversion, miracle work, or martyrdom. As the genre developed, these plays were usually episodic in structure, glorified the acts of a saint of the Church, and frequently appealed to romanticized legend for their manifold demonstrations of the saint's miraculous powers and holiness. ${ }^{18}$ Unfortunately, the destruction of these saints plays by church and government authorities in the period before Elizabeth's coronation was so complete that examples of the genre are rare. ${ }^{19}$ Only two English-language miracle plays survive from the pre-Reformation period, The Conversion of Saint Paul and Mary Magdalene, both from the Digby manuscript (c. 1480-1520). ${ }^{20}$ From the Tudor Reformation itself we also have one Mary Magdalene play, Lewis Wager's The Life and Repentaunce of Mary Magdalene (c. 1550-66), although this is really an allegorized moral interlude shorn of the legendary, non-biblical demonstrations of Mary Magdalen's miraculous powers. ${ }^{21}$ Displacing the miracle plays were the Protestant moral interludes, plays that eschewed hagiographic, legendary depictions of heroes and heroines for the representation of ordinary people in contemporary circumstances, expressing their virtue through moral acts. ${ }^{22}$ 
This account of suppression ought not to be read, however, as extinguishing the impulse that created the earlier religious drama. There is good evidence of an ideological reconstitution of the genre. Although it is well known that English-language plays on scriptural subjects, as distinct from those capitalizing on legendary lore pertaining to post-biblical saints, came into vogue, the matter of the miracle plays lived on, I think it can be shown, in parodic dramatizations of the post-Biblical saints of the Roman Catholic Church. John Bale's lost De Imposturis Thomae Becketi (The Knaveries of Thomas Becket) (c. 1536-39) is one such work. Since its satire necessarily depended on popular pre-Reformation plays venerating Thomas à Becket, of which numerous records survive, ${ }^{23}$ we have good warrant for describing this composition as an "anti-saints play" functioning in a Reformation context. The evidence is by no means entirely inferential, since we have the entire text of Bale's King Johan (1538). There Bale, embracing the Wycliffite position, rejects nearly all the post-biblical saints and follows Foxe's Acts and Monuments in ridiculing the fraud whereby Becket was credited with enacting more miracles than Jesus Christ, "to the number of two hundred and seventy, being so far off from all truth and reason, some ridiculous, some monstrous, vain, absurd, some also blasphemous, and some so impudent, that not only [do] they deserve no credit, as altogether savouring of mere forgery, but also, for very shame, will abash an honest pen to write of them." 24

In two passages particularly, King Johan communicates the attitudes that informed Bale's frontal attack in De Imposturis Thomae Becketi. In the first, Dissimulation, having poisoned the King, gleefully commemorates his own impending death:

To sende me to heauen goo rynge the holye belle And synge for my sowle a masse of Scala Celi,

That I maye clyme vp aloft with Enoch and Heli.

I do not doubte it but I shall be a saynt;

Provyde a gyldar myne image for to paynt.

I dye for the Churche with Thomas of Canterburye.

Ye shall fast my vigyll and upon my daye be merye.

And therfor lete me by shryned in the north yle. $(1: 2127-35)^{25}$

Explicitly invoked as one of a community of false or painted saints, the name of Becket becomes synonymous with Dissimulation. The saint's shrine, indeed the very act of enshrining, becomes an emblem of fraud. In the second passage, Bale has Imperial Majesty chastise Church and Nobility for subduing King John for punishing treason, rape, theft, and murder "in the holy 
spirytualte. / But Thomas Becket ye exalted without reason / Because that he dyed for the Churches wanton lyberte" (1: 2596-98).

In another play of Bale's called Three Laws (c. 1548), the elements of "painting" and "deception," so powerful a part of Reformation anti-theatricalism, are exhibited by the allegorical figure of Idolatry. The character is not only disguised, but misogynistically female — she is a witch — and, significantly for our discussion of La Pucelle, is altered in gender. The thoroughly debased theatricality upon which the vices in Three Laws trade is explicitly tied to popish ceremonies and the idolatrous worship of saints, as when Ambitio urges, "Where as God doth saye, 'No straunge goddes thu shalt have,' / With sayntes worshyppynge that clause we wyll deprave. / And though he commaunde to make no carved ymage, / For a good intent yet wyll we have pylgrymage" (2: 1109-12). Similarly, Avaritia affirms that the laity shall believe in "our holy father Pope," as well as "in pardons and in trentals, / In praynge to sayntes, and in Saynt Frances whoode, / In Our Lady of Grace, and in the blessed roode" (2: 1163-69).

Such theatrical excoriations of Rome, of Romish ceremonies and images, and of the veneration of old-faith spiritual leaders appear in other forms throughout the Tudor period. They were sustained in anti-Catholic interludes, farces, and pseudo-histories enacted on university and public stages. To judge from their titles, their tone (like that of other Reformation discourses) was one of ridicule. Their traces are recorded in such lost plays as Thomas Wylley's Against the Pope's Councillors (1537), Edward VI's De Meretrice Babylonica (The Whore of Babylon) (1548), the Cambridge-mounted Papists (1559), and the Mock Mass (1564), as well as the Edinburgh play Pope, Cardinals, Friars (1598). ${ }^{26}$ Their parodic spirit survives, it seems safe to say, in Christopher Marlowe's Doctor Faustus (1588-92), in which the Pope, his College of Cardinals, and his friars, who appear "with bell, book and candle" (sc. 9, s.d. 99.1), are ridiculed for their gluttony, exorcisms, "superstitious books" (sc. 8.115), rituals, and naïve belief in miracle. ${ }^{27}$

Returning now to the Dauphin's speech, cited above, and comparing it with Bale's play, we see in 1 Henry VI the persisting dramatic engagement with the subject of saints and the manner of their representation. But sharp divergences mark their dramatic treatments. The anti-theatricalism of Bale's Three Laws prompts its author to make Idolatry a character who transparently betrays her deceptiveness so as to foreclose the possibility that her rhetoric might seduce her audience. By contrast, the Dauphin's speech in 1 Henry VI eschews transparency by credibly enacting the seductive effects that Joan's presence works on the French court. The kind of anti-theatricalism that 1 Henry VI does display, especially in respect to Joan's putative miracle work and holiness, requires its audience to penetrate the surface 
representation of Joan and to learn to regard critically the statements of those in the French court who proclaim Joan's miraculous powers. These divergences are particularly striking in respect to tone, for whereas Bale's Three Laws is analytic, caustically satiric, and uncompromisingly didactic, 1 Henry VI displays a sensuous poetic surface undercut by irony. In sum, the manner of Joan's representation affords a latitude of response that Bale's drama in general seeks to prevent. Joan has a voice and genuine sexual power; Idolatry in Bale's Three Laws does not. ${ }^{28}$ Nevertheless, 1 Henry VI does attempt to limit the play of Joan's seductive powers through a strategy of plot - an eventual parodic unmasking or "discovery" of Joan's true nature - an anti-theatrical strategy that calls attention to Joan's fraudulent self-representation and that is anticipated in the first part of the play by an undercutting (but not a determinative) set of poetic ironies.

Crucial to Joan's identity is the Bastard of Orléans's initial description of her as exhibiting saintly powers. His words are riveting:

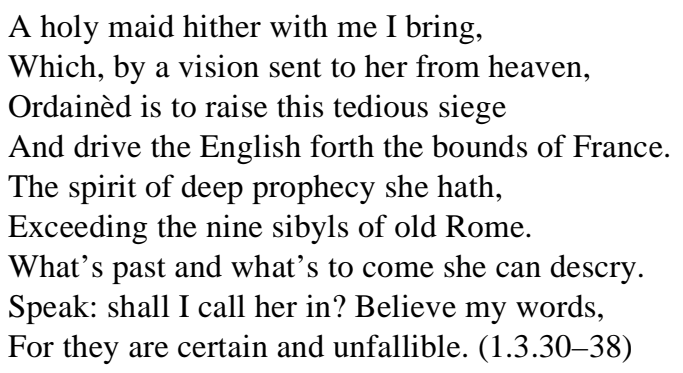

The Bastard's description sets forth several hallmarks of a saint. Acclaiming Joan as "A holy maid," the usual requirement for a female saint, the Bastard attests that she has been visited by a heavenly "vision," another mark of divine favor, and, tellingly, that she has been endowed with a gift of "deep prophecy." Critical to the developing mystique is that the "holy maid" has prophesied the raising of the siege at Orléans and the defeat of the English invaders.

Nevertheless, the extravagance of the Bastard's encomium, particularly the assertion that Joan's gift of prophecy exceeds those of the sibyls, would have aroused anxiety irrespective of the religious convictions of the audience, for the Tudor civic authorities had become so concerned about the destabilizing effects of prophesying that Elizabeth issued a proclamation forbidding soothsaying, divination, or any form of sorcery "for counsel or help." 29 Prophesying, as Lorraine Daston has shown, could have demonic origins, since it was thought that demons could foresee many events otherwise hidden from ordinary humans. ${ }^{30}$ So too the metaphysics of the age held 
that the Devil as false prophet and anti-Christ could seduce others into promulgating a spurious faith. Within this early-modern context, Joan's own supra-natural powers could easily have been viewed as signifying witchcraft rather than heavenly favor. The contemporary problem was always how the two might be distinguished.

This issue is brought to an exquisite point in the closing lines of the Bastard's speech: "Believe my words, / For they are certain and unfallible." Seeking to crush skepticism, he makes emphatic appeal to the Word as against the Image (for La Pucelle has not yet appeared). But despite the Bastard's trumpeting of the Reformers' ideology of the Word, ${ }^{31}$ the source of his authority, we realize, is not the biblical Word at all, for the assertion that his words are "certain and unfallible" echoes the language of papal infallibility, vigorously disputed by Protestants and problematic even for many loyal English Catholics.

The doctrine of papal infallibility, although not formally decreed until 1877, was promulgated by Pope Boniface VIII (b. 1235-d. 1303), whose Bull "Unam Sanctam" declared that every human being must be subject to the Roman pontiff's authority in order to be saved. ${ }^{32}$ England's own Sir Thomas More spoke of the "infallible authoritie of the church" and, very much to the point, the Counter-Reformation Council of Trent reaffirmed in 1564 that "Holy Mother Church has held and holds ... the true sense and interpretation of the holy Scriptures." 33 Archbishop Grindal actually warned Queen Elizabeth "not ... to pronounce too resolutely and peremptorily, quasi ex authoritate. ... It is the antichristian voice of the Pope," 34 and Marlowe parodied these claims of infallibility when he made the Pope in Doctor Faustus boast, "Is not all power on earth bestow'd on us? / And therefore though we would we cannot err" (sc. 8.151-52). This rich contemporary context strongly suggests that the Bastard's identification of Joan as a saintly virgin with supra-human powers is an invitation to an idolatrous worship that belongs only to God. The significance, moreover, of the speech being given to "the Bastard" (a change from the sources), is, I would say, not so much that France is "an illegitimate political upstart," as one critic puts it, ${ }^{35}$ as that the Bastard's claim of infallibility in respect to Joan is a fallacious, bastard claim.

From a theatrical standpoint, the Bastard acts as Joan's stalking horse, creating a fervor of anticipation before La Pucelle enters to demonstrate her powers. A few moments later, the anticipation becomes an epiphany. La Pucelle makes her astonishing - and famous - identification of the disguised Dauphin and immediately proceeds to stake her claim to divine powers: "Be not amazed. There's nothing hid from me" (1.3.47). These powers derive, she explains, from the Virgin, "our Lady gracious" (53), who appeared to her, an ignorant shepherd's daughter, "in a vision, full of 
majesty" (58), in which "Her aid she promised, and assured success" (61). These claims, we note, are the same ones repeated near the end of the play, when Joan reiterates her identity as one "Virtuous and holy, chosen from above / By inspiration of celestial grace / To work exceeding miracles on earth" (5.6.39-41). In apparent confirmation of this miraculous appointment, the Maid testifies that whereas she was formerly "black and swart" (1.3.63), she is now "infus'd" (64) with "That beauty . . . which you may see" (65) and with a martial valor that "exceed[s] my sex" (69). Her testimony, we may note, recalls the N-Town "Crucifixion," in which Veronica's wiping Jesus's face prompts Jesus to respond, "My face is clene pat was blak to se" $(32,1.46)$, and miraculously the cleaned image is preserved on the handkerchief. ${ }^{36}$

This kind of miraculously transformed personality, newly inspired with a heavenly mission, such as we see in La Pucelle's own testament, is typical of pre-Reformation saints plays. Such exhibitions of divine powers operate on the "theme of recurrence," in which the pattern of Christ's miracles is reenacted by his saints, thereby inspiring and renewing faith. ${ }^{37}$ So too, as John Donne preached, the wondrous was often understood to be the first step to faith. ${ }^{38}$ The depiction of La Pucelle's powers pursues the same pattern of development. Put to the test in a trial by combat, Joan promptly passes it by vanquishing the Dauphin. Her modest explanation, "Christ's mother helps me, else I were too weak" (1.3.85), combined with her solemn declaration, "Assigned am I to be the English scourge" (1.3.108), highlights her transformation. To audience members longing for the "Old Faith" where marvelous revelations need not undergo skeptical interrogation, this scene may have aroused nostalgia. Indeed, Clifford Davidson adduces documentary evidence showing that even after the episcopal prohibitions succeeded in suppressing the cycle plays in 1580, they "remained popular even for a long time among people who otherwise found images and scenes in the visual arts to be anathema." 39 Thus without ever endorsing the claims, the composer of the scene creates the conditions for a range of audience responses, including, at this early point, identification with the Maid.

Given the prohibitions against miracle and cycle plays, it is remarkable that 1 Henry VI stages Joan's exhibitions of supernatural favor at all, since such displays were crucial to Joan's burgeoning hagiography. Notwithstanding this theatricalization, neither the Bastard's testimonials nor Joan's demonstrations go uncontested. When Joan, attired in armor, calls attention to her newly infused beauty, she sparks not merely a sexual issue, but a religious one. "Protestant polemicists rage[d] against representations of the Virgin Mary, Mary Magdalene, and the female saints," writes Diehl, "because, they assert, such images portray the female body in such a way as to 
arouse carnal desire." 40 Carnal desire is exactly the issue, for through the introduction of bawdy innuendo 1 Henry VI insinuates that the saintly Maid is really a trollop in the making. Commenting on Joan's forwardness, Reignier whispers, "She takes upon her bravely, at first dash" (1.3.50). Joan herself suggests equivocally that the Dauphin will be fortunate "If thou receive me for thy warlike mate" (71), and although she protests against yielding to "any rites of love, / For my profession's sacred from above," she adds, "When I have chasèd all thy foes from hence, / Then will I think upon a recompense" (1.3.92-95).

Turning the point of focus from Joan to those who behold her, we find this eroticism migrating into a demonstration of idolatrous worship. While the Dauphin's physical defeat before Joan is often interpreted as symbolizing his sexual submission and political emasculation or feminization, these contexts are comprehended in Charles's idolatrous worship of Joan as a saint. The Dauphin's sexual idolatry expresses itself theatrically as he prostrates himself before the amazon warrior whom he fervently worships. Effeminately, Charles confesses, "Impatiently I burn with thy desire. / My heart and hands thou hast at once subdued. / . . / Let me thy servant and not sovereign be" (1.3.87-90), and calls attention to himself as "thy prostrate thrall" (96). This spectacle of idolatrous worship may have evoked mixed reactions, insofar as some audience members may have been pleased to witness this inventive re-presentation of the Petrachan lover submitting to his strong but beautiful mistress; some (both male and female) might long for the relief from normative roles of dominance and submission demanded by Elizabethan culture. But the more prevalent reaction, the one foregrounded by the spectacle, was probably apprehension - or outright contempt of the blasphemy, inasmuch as the scene recollects in exaggerated fashion the old-faith worship of saints. Moreover, the "Homily Against Peril of Idolatry," regularly read in the churches, explicitly addresses this doctrinal link between sexual and spiritual vassalage, warning, "(as Saint Paul teacheth) that they which fell to Idolatry, which is spirituall fornication, should also fall into carnall fornication." 41

As the sensuous image or graven object being worshiped, La Pucelle presents a target. ${ }^{42}$ The male actor playing Joan is not only the false image of a would-be saint, but the doubly false representation of a female saint. Protestants tended to identify the latter with sensuality and with Catholic veneration itself. As Diehl observes, iconoclasts especially tended to collapse images of adoration with images of seduction, which were female. ${ }^{43}$ Moreover, Reformation polemic persistently represented the object of obloquy as both Catholic and female, as is illustrated by the phrase, "Whore of Bablyon." 44 In other words, the worship of images was associated with the 
material body, which was female and dangerously carnal, as against the undefiled "Word" of God, which was construed as male. But ironically the audience is actually furnished with the proscribed sensual image of Joan "La Pucelle." While 1 Henry VI strives to undercut the extravagant worship of Joan as a saint, it cannot do so without the complicity of representing her.

For audiences of the time, there was only one widely available model for this kind of highly charged eroticism in a female saint. It was not the Virgin Mary but Mary Magdalene, known in pre-Reformation and Reformation times as Christ's lover. Called a "Venus in sackcloth" who embodied "the paradox of erotic asceticism," Mary Magdalene exhibited a desire that was constructed as erotic — she is ravished by Christ — without being sexual, although even this identity was fraught with tension for Protestant reformers. ${ }^{45}$ Our somewhat coarser modern sense of genital sexuality conflates the erotic and the sensual, but in Renaissance psychology love attacks as a beam emanating from the object or image to the eyes of the beholder, attacking the imagination and then traveling downward into the heart, where it lodges. ${ }^{46}$ From this place sexual desire can (but need not necessarily) arise. Charles's worship of his female saint proceeds in just this way - from admiration to eroticism to sexual longing. The venereal quality of his service is given rhapsodic voice when the Dauphin addresses La Pucelle as "Bright star of Venus, fall'n down on the earth," exclaiming, "How may I reverently worship thee enough?" (1.3.123-24). The invocation of the pagan Venus suggests, of course, carnal desire, particularly given the use of "fall'n," whose suggestiveness anticipates Joan's later confession of promiscuity.

Charles's besotted idolatry manifests his personal and moral inadequacies. But La Pucelle herself, as a displacement of male desire, is held before our eyes as a graven image with the dangerous power to enchant. That this power resides in La Pucelle and is not solely the product of Charles's weakness is demonstrated when Burgundy hears her silver-tongued description of France's bleeding wounds and feels himself mysteriously moved to defect from his English allies, thereby sealing the outcome of the Hundred Years' War. "Either she hath bewitched me with her words," the bewildered Duke mutters, "Or nature makes me suddenly relent" (3.7.58-59). The "Or" suggests Burgundy's puzzling over the possibility that Joan has awakened in him an affective sympathy for suffering France. But the reflection is less than determinative, since the intimations of sorcery and seduction are more prominent. These latter also resonate in Charles's earlier entreaty, "Speak, Pucelle, and enchant him with thy words" (3.7.40). In this manner, a correlative to the Dauphin's idolatrous submission to La Pucelle's sensuous image insinuates itself into 1 Henry VI, as Burgundy submits to La Pucelle's 
bewitching words. In short, the play moves from an idolatry of the bodily image to an idolatry of the beguiling word.

A second dimension of La Pucelle's saintly character is her function as prophet. Many female saints of the Old Faith were venerated for their virgin purity and steadfastness against horrible tortures, but only a few, Mary Magdalene chief among them, were venerated because of their prophetic powers. These powers too were challenged by reformers as the ignorant products of legend. In other contexts, moreover, prophesying was identified with the black arts (as the Duchess's conjuration scene in 2 Henry VI demonstrates), which were associated in turn with Catholic practices. The idea also appears from another direction, when the Dauphin ecstatically compares Joan to the foremost Muslim prophet: "Was Mahomet inspirèd with a dove? / Thou with an eagle art inspirèd then" (1.3.119-20). Audiences of the medieval period would have responded to Mahomet as a demon, while early-modern audiences also saw him as a synonym for heresy, schism, and the anti-Christ. The Corpus Christi cycles, for example, programmatically linked his name to Herod, the would-be slayer of Christ. ${ }^{47}$ With the Reformation writers began associating Mohammed with lechery, the Whore of Babylon, the Pope, and false Revelation. ${ }^{48}$

The Dauphin inadvertently raises this specter of false revelation when he speaks of the inspiration of the dove. In Christian iconography the dove symbolized divine revelation - but not when linked to Mohammed. Whereas Muslims affirm that a dove spoke in Mohammed's ear, the widely circulated defamatory Christian interpretation was that Mohammed cunningly taught the dove to be fed meat out of his ears. ${ }^{49}$ The Dauphin is oblivious of this antithesis, just as he is of the implication that his image of Joan as a "fall'n" star of Venus associates her with that archetypal false god, Lucifer. ${ }^{50}$ These ironies culminate in the Dauphin's scene-closing protestation, "No prophet will I trust, if she prove false" (1.3.129). Joan, the verse invidiously suggests, is akin to just such spurious prophets and false gods.

Through the Dauphin 1 Henry VI initiates still another critique of idolatry - the Romish worship of non-biblical saints. This subject is announced following the Maid's victory at Orléans, at which point the Dauphin depicts his champion as fit for hagiography. In Shakespeare's time, Joan of Arc had not yet been canonized. Indeed, she was beatified only in 1909 and canonized in $1920 . .^{51}$ Nonetheless an indigenous movement to rescind the verdict of heresy against her began in France soon after her burning in 1431. The formal procedures of rehabilitation ended in 1456 in Rouen with the official pronouncement that Joan of Arc's "trial and sentence ... [had been] contaminated with fraud, calumny, wickedness, contradictions, and manifest errors of fact and law." 52 For the French, the Maid of 
Orléans was now officially a martyr, providentially appointed to rid her country of English armies.

On the other side, Holinshed and Hall, whose sources were English, French, and Burgundian, sought to discredit the cultish, saintlike characterization of "the maide of GOD," as Hall had it. Hall inveighs specifically against La Pucelle's "causyng herself to be honored and worshipped of many, as a woman sanctified." His excoriations are so vitriolic that they resemble Foxe's against Becket. The point to which Hall tirelessly returns is that "diuerse French writers affirme her to be a saincte in heauen," that she was "honored or worshipped as a sainct sent from God," but that she was "a false prophetisse" and "supersticious sorceresse," to whom the citizens of Orléans "buylded in the honor of her, an Image or an Idole." The idolatrous worship of a degenerate woman is salient. In fact, Hall concludes his diatribe by aiming squarely at the claims of La Pucelle's saintliness "so that, if these morall vertues [were] lackyng, she was no good woman, then it must nedes, consequently folowe, that she was no sainct." 53

Yet "the real target," as Richard Hillman puts it, was "the instauration of Jeanne's myth ... as an essential feature of the national consciousness of France." ${ }^{4}$ At the time that 1 Henry VI was performed, the "high festival" honoring La Pucelle imagined by the Dauphin had long become an established fact, for the city fathers of Orléans had instituted an annual religious procession and festival organized around the ceremonial presentation of $L e$ Mistère du siège d'Orléans, an unrelenting epic drama of over 20,500 lines from mid-fifteenth century Orléans commemorating Joan as France's savior and de facto saint for raising the siege of the city ${ }^{55}$ The veneration of Joan of Arc was thus well under way in France when Hall, in scornful rebuttal, composed his chronicle. Moreover, Joan's formidable myth continued to grow throughout the mid- and late-sixteenth century. Evidence of this appears in Fronton du Duc's L'histoire tragique de la Pucelle de Dom-Rémy, a consequential play represented before Charles III, Duke of Lorraine, in 1580 and published in 1581.56 The play illustrates the blossoming myth of Joan's miracle work and saintliness, which continued to feed "mystical Catholic fantasies of [French] national destiny." 57 England's own 1 Henry $V I$ must be understood as taking place in fierce opposition to this growing trend of Joan's hagiography across the channel.

Indeed, Du Duc's La Pucelle and 1 Henry VI both draw on a common fund of legendary matter, depicting, for example, Joan as an amazon and aligning her with the figure of Deborah, albeit from very different perspectives. So too, whereas Du Duc emphasizes the cruelty and prolongation of Joan's sufferings as the onlookers cry, "Coupe, coupe, bourreau, la corde et plus n'attends! / Tu l'as assez rôtie'" (11. 2348-49), l Henry VI seeks to 
curtail this charge by having Warwick order plenty of pitch "so her torture may be shortenèd" (5.6.59). Similarly, whereas La Pucelle vivifies the legend that Joan's heart remained unburnt - a testament to her purity and that a white dove rose, phoenix-like, from her ashes, 1 Henry VI tells us flatly that Joan will "consume to ashes" (5.6.92), and its lone association of Joan with a dove, appears, as we have seen, in the heretical context of "Mohammed[an]" inspiration (1.3.119). ${ }^{58}$ These competing elements reveal a great contention, in fact an international struggle, to render the soul of Joan/Jeanne d'Arc —either as a Catholic saint or as an imposter and witch.

Within England itself Joan's legend continued to resonate in other ways. Leah Marcus has observed that the representation of Joan of Arc as national hero and virgin saint bears a striking, albeit ambiguous, relationship to the pre-Reformation worship of the Virgin Mary and to the displaced secular celebration of Elizabeth as "the Virgin Queen." ${ }^{59}$ Building on her contribution, we may posit a broader post-Reformation context that links Joan not only to the Virgin, the greatest of all the female saints, but also to the papist worship (as Protestants would put it) of female saints per se, especially Mary Magdalene. Centered in Provence, the cult of Mary Magdalene offered a spectacular point of reference and attack. As a prostitute made holy by her love of Christ, Mary Magdalene was venerated as an intercessor and patron saint, and her shrine in Vézelay, reputed to hold her relics, became a famous center for pilgrimages. ${ }^{60}$ Since, moreover, her identity originates in the Gospels, her veneration survived the English Reformation - her feast day being restored to the church calendar in 1541 (most others were not), after having been abrogated several years earlier. ${ }^{61}$ To this day her name is retained in colleges in Oxford and Cambridge, as it is in numerous English churches. Nonetheless, Mary Magdalene's status fell as scholarly reformers attacked her legend, using their research to problematize the miracles attributed to her and the quasi-divine status she had acquired from the eleventh to fifteenth centuries, especially under the influence of Jacobus de Voragine's Legenda Aurea. ${ }^{62}$ Biblical scholars showed, furthermore, that her legend and very identity were founded on a false assimilation of several discrete biblical figures called Mary. ${ }^{63}$

In the only speech explicitly prophesying Joan's sainthood - "Joan la Pucelle shall be France's saint" (the speech with which I began this essay) the Dauphin employs a sensual imagery that precisely pictures the kind of ceremonial worship of saints that the Elizabethan government forbade. Striking the keynote, Charles imagines that "all the priests and friars in my realm / Shall in procession sing her endless praise" (1.8.19-20). While the speech glances at priests and friars, whose derogation was commonplace in early-Elizabethan plays and among the University Wits, ${ }^{64}$ the fuller object 
of ridicule is popish ceremony. We hear it in Marlowe's mocking spectacle of Roman Catholic ceremony when "Monks and Friars [enter] singing their procession" (Doctor Faustus, sc. 8, s.d. 89.2), and we hear it when Charles imagines that Joan's ashes "Transported shall be at high festivals" (1.8.26). With this extravagantly imagined procession we may juxtapose Elizabeth's proclamation on religion, which stipulates that curates and their parishioners "shall take away, utterly extinct, and destroy all shrines . . . pictures, paintings, and all other monuments of feigned miracles, pilgrimages, idolatry, and superstition, so that there remain no memory of the same in . . . their churches and houses." 65

Charles's vow to "rear" a "pyramid" to Joan, like his hyperbolic invocations of Rhodope of Memphis and Darius's coffer, also suggests pagan idolatry, while the anticipated gaudy display of La Pucelle's ashes imaginatively reenacts the cultish worship of saints' relics that Reformation polemicists ceaselessly attacked. In contrast to the plainness of Talbot's English tomb, apposite to a Protestant nation, Joan's tomb is imagined in a profusion of ornateness whose affective power belongs to the dangerous sensuality of saint worship. The Dauphin's description of "an urn more precious / Than the rich-jewelled coffer of Darius" actually fetishizes the place of interment in a way that recalls the kind of saint worship that had become famous at Vézelay, where "the saint's relics were translated to appropriately opulent reliquaries. Mary Magdalen's head was placed in a golden reliquary studded with precious gems, while her body was placed in a separate but equally precious vessel." 66 This is not to say that Mary Magdalene is the specific point of attack, but to illustrate that 1 Henry VI carries out the functions of an anti-saints play.

The whole scene obviously contravenes the spirit of the reformed religion, with its homiletic injunction that the raising of "idols and images" with "outward ceremonies" and "the outragious decking of Temples and Churches, with gold, siluer, pearle, and precious stone, shall be confuted." 67 Yet it must also be remembered that in 1564 the Catholic Counter-Reformation reaffirmed "that the Saints ... are to be venerated and invoked ... [and] their relics are to be venerated." 68 We may also observe that in the transfigured world of Elizabethan England, where not everyone shared the iconoclasts' uncompromising vision of the Reformed Church, where loyal Englishmen of Catholic faith still dwelt in large numbers, ${ }^{69}$ and where even conforming audience members may have longed for a lost richness and a lost relatedness to once-venerated (and here female) saints, the Dauphin's exotic vision of the worship of a saint may have fulfilled a nostalgic as well as a hortatory function. Indeed, inasmuch as 1 Henry VI presents richly 
poetic descriptions of the saint worship it seeks to impugn, it generates the very iconography it holds up to ridicule.

As a chronicle history, 1 Henry VI exhibits a different kind of compensatory strategy in depicting Joan from the English viewpoint. Whereas the French scenes depend on thinly veiled ironies to undercut the Dauphin's idolatry and Joan's prospective sainthood, the English scenes work by direct refutation. There Joan is repeatedly execrated as a "Devil or devil's dam" (1.7.5) and "a witch" (7) who serves Satan. By the third act the mythic Talbot, helpless before her unassailable powers, ascribes his military defeats to "that damnèd sorceress" (3.4.3), "that railing Hecate" (3.5.24), the "Foul fiend of France, and hag of all despite" (12) - in short, to witchcraft.

This dichotomous perspective carries theological force. Bale's prose works, Hall's Chronicle, and Foxe's Acts and Monuments all emphasize that a person possessing supernatural and especially prophetic powers is either of God or of the devil - in La Pucelle's case, either saint or sorceress. Whatever uncertainty audience members may harbor about Joan's true identity is resolved in the éclaircissement in which La Pucelle is shown conjuring with "charming spells and periapts" (5.3.2) and invoking, "You speedy helpers . . . / Under the lordly monarch of the north" (5-6). This scene, incidentally treated and usually derogated as an unsophisticated descent into spectacle — " "a gaggle of stagy fiends" as one critic colorfully puts it — actually makes a crucial point. ${ }^{70}$ It works as the play's long-awaited revelation, in which the source of La Pucelle's mysterious powers is shown to be the "familiar" (10) fiends who hitherto have offered Joan "accustomed diligence" (9). Such trafficking as Joan engages in was really no joking matter. Widely practiced both for good and ill, divination or sorcery was proscribed from the Middle Ages, and Elizabeth's 1559 injunction specifically forbade the use of "charms, sorcery, enchantments, witchcrafts, soothsaying, or any like devilish device." 71 Joan's futile bartering of her blood, a limb, and then her body if the devils will continue to assist her constitutes a prima facie demonic compact with her familiars. Since the prescribed penalty for conjuring evil spirits under the Act of 1563 was death, ${ }^{72}$ the explicit dramatization of Joan's demonic conjurations was presumably aimed at justifying her subsequent execution as a witch.

This revelation also bears a striking, inverted relationship to pre-Reformation saints plays representing conversions, miracles, and martyrdom. Despite the paucity of surviving saints plays, the logic of parodic inversion - the putative saint-proved witch - can be traced using the two extant Mary Magdalene plays as positive models. Wager's Protestant Life and Repentaunce of Mary Magdalene theatricalizes the moment of conversion in a spectacular scene. There the revelatory moment occurs when "Infidelitie 
runeth away. Mary falleth flat downe" (s.d. 1285.1), and the "vii. diuels which haue hir possessed" (1283) are exorcized, "roare[ing] terribly" (s.d. 1285.2). ${ }^{73}$ The pre-Reformation Digby Magdalene portrays the same event (s.d. 691.1). In the inverted pattern of 1 Henry VI, the comparable crystalizing moment occurs when La Pucelle, instead of casting out her devils, conjures them up. Unlike Mary Magdalene, the prototype for the abandoned woman, Joan is filled with longing not for Christ but for her devils. ${ }^{74}$ Such an outcome is less a development of character than it is a revelation of demonic affiliation, an epiphany of devil-worship.

For all its staginess, the conjuring scene is private, since only the audience is privy to it. What remains for the audience to witness is the fulfillment of the expectation that La Pucelle will be publicly exposed, humiliated, and punished. This takes place in the penultimate scene, in which Joan, now a captive, furnishes a first-act reprise of her heaven-appointed mission - only this time her rhetoric is authoritative. After denying her shepherd father, she declares herself

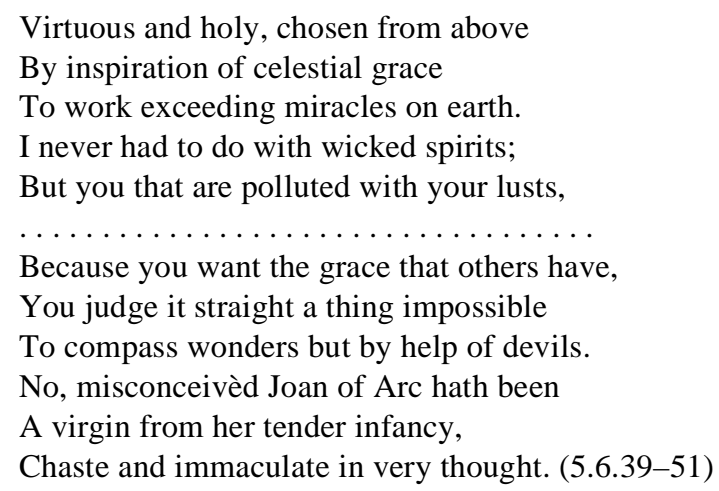

We need only recall the bravado with which Infidelitas in Bale's Three Laws claims, "I am a prophete by hygh inspiracyon led" ( 1.1375$)$, to recognize that the Reformation features of Tudor drama had long conditioned audiences to treat with skepticism extravagant claims of supra-natural powers. Moreover, Joan's reaffirmation of divine appointment and her now explicit claim to perform "exceeding miracles" align her speech with the kind of claims made in pre-Reformation saints plays. But as the scene unfolds, it turns on its head three foundational aspects of Joan's saintly identity, the very grounds of her veneration: her status as holy virgin, miracle worker, and martyr. Instead of inspiring faith, the scene inspires ridicule and judgment.

The post-Reformation lampooning of these features of La Pucelle's identity is thematic and bears a close but inverted relationship to English pre-Reformation religious drama. Most striking is the dismantling of Joan's 
acquired name, "La Pucelle." Fearing to be burnt, Joan protests, "I am with child . . . / Murder not then the fruit within my womb" (5.6.62-63). This word-choice obviously echoes Luke - "Blessed art thou among women, because the frute of thy wombe is blessed" 75 - and parodies as well Gabriel's address in the Annunciation pageants, repeatedly presented in the Corpus Christi cycles. There is also a marked antithesis to the reformed Mary Magdalene, who assimilates features of the Virgin and comes to be addressed in similar terms. After Mary Magdalene works a fertility miracle in which the childless Queen and King of Marseilles conceive a child, the joyous king addresses her in terms formerly reserved for the Virgin Mary: "Heyll be pou, Mary! Ower Lord is wyth thee!" (Digby Magdalen, 1. 1939). In marked contrast to Du Duc's La Pucelle, and especially to Le Mistère du Siège D'Orléans, which draws pious typological parallels between the Virgin Mary and Joan the Maid, ${ }^{76}$ York's taunting riposte to Joan, "Now heaven forfend - the holy maid with child?" and Warwick's accompanying jeer, "The greatest miracle that e'er ye wrought!" (5.6.65-66), call attention to the typology of the fertile virgin saint. However, the sole purpose of these invocations is to re-label La Pucelle as fraud and whore, Mary's and Mary Magdalene's antitype. Such a transformation of the sacred female into the polluted harlot is, we have seen, a characteristic strategy of Protestant invective.

Joan's shameless prevarications, in which three men, including the Dauphin, are named as possible fathers - "I think she knows not well - I There were so many - whom she may accuse" (5.6.80-81) - clearly recollect familiar comic features of the religious cycle plays, as, for example, when Joseph in the York mystery of Joseph's Trouble about Mary expresses his unfounded fear about Mary's conception, asking, "Hir sidis shewes she is with childe. / Whose ist Marie?" (11. 102-3), and again, "But who is pe fader? Telle me his name" (177), and again, "pe fadir tell me, Marie" (187), and yet again, "Who had thy maydenhede Marie?" (207). By contrast, the virgin's pregnancy gives full play to the ridicule of the mystique of "La Pucelle." This is one reason why the tone, instead of being gently humorous, as in the Joseph plays, moves from the parodic to the farcical and the satiric. The contrasting tone bespeaks a contrasting typology. What the audience witnesses in Joan's behavior is the precise opposite both of the Virgin Mary and, more precisely, Mary Magdalene, for the Magdalene is the penitent harlot proved miracle worker and saint, while Joan, heralded as miracle worker and saint, cravenly presents herself, under duress, as a sorcerer and self-proclaimed harlot.

The climactic event toward which the satiric exposure leads is, of course, Joan's execution. Recent interpretations of this event have focused 
on topical contexts. Jackson reads Joan's burning in relation to the witchcraft executions of poor women in England (although, as she acknowledges, they were hanged, not burned), arguing that these circumstances could have aroused sympathy for Joan, since, as Nina Levine argues, pointing to Polydore Vergil, "Sixteenth-century presentations of Joan were by no means monovocal."77 So, too, Marcus believes that since Joan's burning "can be assimilated to the iconoclastic pattern of Protestant ritual burning" of false images of Elizabeth, "the play stimulates its viewers to spin out their various dark fantasies about Elizabeth so that all such speculations can be thrown in one vast heap and consumed together." 78 Without attempting to exclude such pertinent readings, I propose that Joan's burning bore a greater cultural immediacy, one that the contemporary context of martyrdom for the Reformed Church can best illuminate. These help explain not only the climatic burning, but the satiric ridicule of Joan integral to it.

Nina Levine has pointed to the discomfort that modern audiences may feel and that contemporary audiences may have felt at "the sight of the maid's brutal end."79 Indeed, although 1 Henry VI spares its audience from seeing the victim burn and stresses that the burning will not be prolonged, it is quite unreserved about the horrific act itself: "Spare for no faggots. Let there be enough. / Place barrels of pitch upon the fatal stake" (5. 6.56-57). The last words spoken to Joan do not flinch in announcing her fiery end: "Break thou in pieces, and consume to ashes, / Thou foul accursèd minister of hell" (92-93). But if Levine is right in suggesting that this scene arouses sympathy for Joan, we must ask how this view can be sustained in the face of the play's untempered, final condemnation of her as a "minister of hell"? How can the play unflinchingly present such a heartless conclusion? By way of response, I suggest that Foxe's Acts and Monuments - England's "Book of Martyrs" - provides the most powerful counter-examples and the ones closest at hand for understanding Joan's burning.

The influential teachings of the "Book of Martys" made their way into Elizabeth's injunctions on religion in 1559; the book itself was one of the most frequently owned in English homes, and in 1571 by canon law was placed in the cathedral churches of England. ${ }^{80}$ Its full-page engravings of the burnings of William Tyndale, Nicholas Ridley, John Philpot, Hugh Latimer, Thomas Cranmer, Anne Askew, and the other martyrs constituted a Protestant hagiography to which even the illiterate could ardently respond. For followers of the Reformed Church, the readiness to embrace martyrdom was the sine qua non of the new sainthood. ${ }^{81}$ The emergent hagiography of the Church of England necessitated sharply differentiated responses to its new-made saints, as against their counterparts or counter-claimants from the Roman Church. This sharp differentiation we can apprehend by comparing 
the representation of Joan with that of any of these Protestant martyrs. Their reported steadfastness and calm provided exemplars as antithetical to this "saint" of France as could be.

Of all the examples at hand, none is more pertinent to the representation of Joan's burning than the burning of Anne Askew, the preeminent female martyr of the English Reformation, on whose examination, trial, sufferings, and death Foxe lavished over fifteen pages. ${ }^{82}$ As a counterpoint to Joan, no contrast could be sharper. Faced with torture, she was urged to accuse others but refused. Urged to recant her religious convictions, she again refused, even after being twice tortured on the rack. So grievous was her torment that she was brought to her execution in a chair, since she could no longer stand unaided. Her sex did not go unnoticed either, for before her torturers put her on the rack they inquired of her, evidently as a test of her resolve, whether she was "with child"; but unlike Joan, who in 1 Henry VI gratuitously volunteers such information to put off her fate, Anne Askew responded, "'Ye shall not need to spare for that, but do your wills upon me." 83 In the moments before her immolation, Anne, according to Foxe's report, remained steadfast and composed in the manner of the true martyr and even refused the King's pardon, offered if only she would recant.

In considering the radically different parodic contumely that suffuses the scene of Joan's burning in 1 Henry VI, we should not forget that the strategy of ridicule combined with righteous judgment is a hallmark of Reformation polemicists. As we have already seen, it repeatedly appears in the anti-saints satire of Bale's plays. It even appears in Foxe's own contumacious response to a Catholic priest in fear of death by burning, for after describing the trials and burnings of the English martyrs as "lamentable and bloody tragedies," Foxe narrates how a Catholic preacher called Dr. Smith supposed (on the basis of a false report) that he and his congregation were about to be consumed by fire. ${ }^{84}$ Then, exhibiting a sensibility most moderns can only marvel at, Foxe labels Smith's terror a "merry and comical spectacle, whereat thou mayest now laugh and refresh thyself." 85 The narrative, it is true, is not about a real burning, but it is fully of a piece with other Reformation parodies of old-faith beliefs and practices. No different is the closing action of 1 Henry VI, in which Joan's self-declared promiscuity, her claim of pregnancy, and the English lords' mockery of her plight comprise a farcical spectacle of the false martyr and would-be saint.

Distasteful as it may be for readers today to entertain the notion that 1 Henry VI divides those in darkness from the ones who walk in light, and that it exhibits no compunction in consigning Joan to the flames, this is the perspective that Foxe's Book of Martyrs opens on the play. Of course, some contemporary audience members may have resisted the typology that Foxe's 
book, the miracle plays, and the polemics against idolatry cast upon this play, and they may even have responded with sympathy to Joan's career. Nonetheless, if the several contexts I have just named were alive for members of the Elizabethan audience - as I have argued they were - then 1 Henry VI is implicated in the project of building and fortifying the English Protestant nation. This is why the play so freely reenacts as parody the burning of Joan as a false martyr, prophet, and saint, and why it works so unstintingly to refute Joan la Pucelle's hagiographical elevation in the mid-late sixteenth century in Rouen, Orléans, and throughout France as that nation's premier miracle worker and Catholic martyr.

If the analogical and typological contexts I have adduced over the course of this essay have any merit, they allow us to resituate 1 Henry VI so as to understand it not just as a "secular" national epic or even as a portrait of the warrior woman, but also as in a significant sense a "religious" play about sainthood, idolatry (especially in respect to female seductiveness), and martyrdom. Seen from this set of dramatic and non-dramatic perspectives, 1 Henry VI is an important work for which I would make this substantial claim: it is the most strategically developed dramatic inversion of a saints play that we have from the post-Reformation period.

Binghamton University, State University of New York

\section{Notes}

This essay profited from the extensive knowledge and counsel provided by Norman T. Burns, professor emeritus of Binghamton University, and Richard Hillman, professor of English at the Université François-Rabelais (Tours).

1. Louis Montrose, The Purpose of Playing: Shakespeare and the Cultural Politics of the Elizabethan Theatre (Chicago: University of Chicago Press, 1996), pp. 33, 30.

2. Ibid., pp. 32n21, 33-35. See Steven Mullaney, The Place of the Stage: License, Play, and Power in Renaissance England (Chicago: University of Chicago Press, 1988). Mullaney (p. 48) develops the view of Joel B. Altman, The Tudor Play of Mind: Rhetorical Inquiry and the Development of Elizabethan Drama (Berkeley: University of California Press, 1978), p. 269, that the secular drama posed extended questions rather than solutions to problems.

3. Michael O'Connell, “The Idolatrous Eye: Iconoclasm, Anti-Theatricalism, and the Image of the Elizabethan Theater," ELH 52 (1985): 281, 305, 286-87.

4. Huston Diehl, Staging Reform, Reforming the Stage: Protestantism and Popular Theater in Early Modern England (Ithaca, NY: Cornell University Press, 1997), pp. 9-39. The continuing productivity of the debate is evident in Anthony B. Dawson and Paul Yachnin, The Culture of Playgoing in Shakespeare's England: A Collaborative Debate (Cambridge: Cambridge University Press, 2001), pp. 21-29, wherein Dawson holds that theater and theology ought to be seen as a productive set of interrelationships (p. 29). 
5. Citations from The First Part of Henry the Sixth, otherwise referred to as 1 Henry VI, are from Jean E. Howard's edition in The Norton Shakespeare, general ed. Stephen Greenblatt (New York: W. W. Norton, 1997).

6. On saints' holidays, the Church calendar, and the plays and performances organized around them, see R. Chris Hassel, Jr., Renaissance Drama and the English Church Year (Lincoln: University of Nebraska Press, 1979), pp. 1-21.

7. Gabriele Bernhard Jackson, “Topical Ideology: Witches, Amazons, and Shakespeare's Joan of Arc," English Literary Renaissance 18 (1988): 40-65.

8. Leah S. Marcus, Puzzling Shakespeare: Local Reading and its Discontents (Berkeley: University of California Press, 1988), pp. 60-66, 68-70, 82, 100.

9. Ibid., pp. 67, 84-85. See also Patrick Collinson, "From Iconoclasm to Iconophobia: The Cultural Impact of the Second English Reformation," in The Impact of the English Reformation, 1500-1640, ed. Peter Marshall (London: Arnold, 1997), pp. 278-308.

10. Jackson, pp. 42-43, stresses that discontinuous representation of Joan's sexual nature is characteristic of 1 Henry VI. See also Kathryn Schwarz, Tough Love: Amazon Encounters in the English Renaissance (Durham, NC: Duke University Press, 2000), p. 82.

11. On La Pucelle's relationship to Petrarchism and the chivalric tradition, see Nancy A. Gutierrez, "Gender and Value in 1 Henry VI: The Role of Joan de Pucelle," Theatre Journal 42 (May 1990): 188-89, and Nina S. Levine, Women's Matters: Politics, Gender, and Nation in Shakespeare's Early History Plays (Newark: University of Delaware Press; London: Associated University Presses, 1998), pp. 32-33.

12. Coppélia Kahn, Man's Estate: Masculine Identity in Shakespeare (Berkeley: University of California Press, 1981), p. 55.

13. The breadth of recent feminist interpretations of Joan has been in part a reaction to the narrower political-military interpretations that preceded. If La Pucelle's witchcraft is read in the manner of E. M. W. Tillyard, Shakespeare's History Plays (1944; rpt. New York: Barnes \& Noble, 1969), pp. 164-65, as a providential curse upon England for Henry IV's usurping the English throne, or if Joan is viewed, in the manner of David Riggs, Shakespeare's Heroical Histories: Henry VI and Its Literary Tradition (Cambridge, MA: Harvard University Press, 1971), pp. 102-7, only as the heroic antagonist to Talbot, then her protean role as miracle-working-saint-proved witch is interpreted almost exclusively in military or political terms.

14. Neither Shakespeare's primary authorship of Henry VI, Part One, nor its relationship to Henry VI, Part Two and Henry VI, Part Three, as the First Folio entitles them, is a settled matter. Many scholars hold that Henry VI, Part One was composed after the second and third parts, which was formerly a distinct two-play entity entitled The First Part of the Contention of the Two Famous Houses of York and Lancaster and The True Tragedy of Richard Duke of York and the Good King Henry the Sixth. Arguments for the discrete composition of 1 Henry VI are made by John Dover Wilson, ed., The First Part of King Henry VI (Cambridge: Cambridge University Press, 1952), pp. xii-xx, and Stanley Wells and Gary Taylor, with John Jowett and William Montgomery, in William Shakespeare, A Textual Companion (Oxford: Clarendon Press, 1987), pp. 111-13. Similarly, although many scholars follow the Folio in assigning 1 Henry VI to Shakespeare, arguments on the other side are substantial. Dover Wilson (pp. xiv-xxii) made the case, widely respected, for multiple authorship and, in particular, for the participation of Thomas Nashe. Gary Taylor's "Shakespeare and Others: The Authorship of Henry the Sixth, Part One," in Medieval and Renaissance Drama in England 7 (1995): 145-205, adduces good evidence 
that Henry VI, Part One was composed by as many as four authors, including Nashe, who held pronounced reformation views, and that Shakespeare's part in that play may have been limited to Act Two, scene four, and Act Four, scenes 2-7 (the last to line 32). For these reasons, I scrupulously avoid assuming that Shakespeare is (or is not) the principal author of 1 Henry VI.

15. Tudor Royal Proclamations, ed. Paul L. Hughes and James F. Larkin, 3 vols. (New Haven, CT: Yale University Press, 1969), 2: 115-16.

16. See the accounts of Montrose, pp. 24-25, and especially Harold C. Gardner, Mysteries' End: An Investigation of the Last Days of the Medieval Religious Stage (1946; rpt. Hamdon, CT: Archon Books, 1967), pp. 65-93. On the eviscerations of the Marian plays, see Clifford Davidson, "'The Devil's Guts': Allegations of Superstition and Fraud in Religious Drama and Art during the Reformation," in Iconoclasm vs. Art and Drama, ed. Clifford Davidson and Ann Eljenholm Nichols, Early Drama, Art, and Music Monograph Series 11 (Kalamazoo: Medieval Institute Publications, Western Michigan University, 1989), pp. 121-22.

17. John Wasson, "The Secular Saint Plays of the Elizabethan Era," in The Saint Play in Medieval Europe, ed. Clifford Davidson, Early Drama, Art, and Music Monograph Series 8 (Kalamazoo: Medieval Institute Publications, Western Michigan University, 1986), p. 241.

18. David Bevington, ed. Medieval Drama (Boston: Houghton Mifflin, 1975), p. 661.

19. On this point see the compelling data of Glynne Wickham, Early English Stages, 1300 to 1660, vol. 3 (London: Routledge \& Kegan Paul; New York: Columbia University Press, 1981), pp. 60, 183, and David L. Jeffrey, "English Saints' Plays," in Medieval Drama, ed. Neville Denny, Stratford-Upon-Avon Studies 16 (London: Edward Arnold, 1973), pp. 69-70.

20. There also survives the 1504 manuscript of the Cornish-language miracle play, Beunans Meriasek (St. Meriasek). Unless otherwise noted, dates of plays are from Alfred Harbage and S. Schoenbaum, Annals of English Drama, 975-1700, 3rd ed., rev. Sylvia Stoler Wagonheim (London: Routledge, 1989).

21. On the evolution of this post-Reformation dramatic mode, see Peter Happé, "The Protestant Adaptation of the Saint Play," in The Saint Play in Medieval Europe, ed. Davidson, pp. 232-35.

22. Murray Roston, Biblical Drama in England from the Middle Ages to the Present Day (Evanston, IL: Northwestern University Press, 1968), pp. 70-71.

23. For an account of Becket in medieval drama, see Clifford Davidson, "The Middle English Saint Play and Its Iconography," in The Saint Play in Medieval Europe, ed. Davidson, pp. $31-122,52-60$.

24. The citation is from John Foxe, The Acts and Monuments of John Foxe, A New and Complete Edition, 8 vols., ed. Stephen R. Cattley (London: 1837-41), 2: 250. For the English Reformation's embracing of Wycliff and the inevitable recoil from Becket as saint, see Happé, "Protestant Adaptation," p. 214, and Thora Balslev Blatt, The Plays of John Bale: A Study of Ideas, Technique and Style (Copenhagan: G. E. C. Gad, 1968), p. 50.

25. All citations of Bale are from The Complete Plays of John Bale, 2 vols., ed. Peter Happé (Cambridge: D. S. Brewer, 1986) and appear in the text. Dates of Bale's plays refer to this edition as well.

26. The plays and their brief descriptions are cited in Harbage and Schoenbaum, pp. 26-27, 30-31, 36-37, 40-41, 70-71. 
28 / Renaissance and Reformation / Renaissance et Réforme

27. Citations from, and the range of dates for, Doctor Faustus are from the edition of John D. Jump, The Revels Plays (London: Methuen, 1962).

28. Many feminist scholars discern this kind of agency in Joan. See Katherine Eggert, Showing Like a Queen: Female Authority and Literary Experiment in Spenser, Shakespeare, and Milton (Philadelphia: University of Pennsylvania Press, 2000), pp. 57-58; Jean E. Howard and Phyllis Rackin, Engendering a Nation: A Feminist Account of Shakespeare's Histories (London: Routledge, 1997), pp. 43-64; Phyllis Rackin, Stages of History: Shakespeare's English Chronicles (Ithaca, NY: Cornell University Press, 1990), pp. 151-61; and Jackson, pp. 56-59. But $c f$. Gutierrez, pp. 191-92.

29. Tudor Royal Proclamations, 2: 126.

30. Lorraine Daston, "Marvelous Facts and Miraculous Evidence in Early Modern Europe," Critical Inquiry 18 (1991): 107.

31. Throughout this section I am indebted to O'Connell's work (esp. pp. 286-87) on the relationships between iconoclasm and the Word.

32. Catholic Encyclopedia, Online Edition by Kevin Knight, Copyright 2002, s.v. "Boniface VIII" and "Unam Sanctum" (http://www.newadvent.org/cathen/02662a.htm and http://www.newadvent.org/cathen/15125a.htm [March 15,2003]).

33. Henry Bettenson, Documents of the Christian Church (1943; rpt. New York: Oxford University Press, 1956), p. 374; on More, see OED, "infallible."

34. Cited by H. G. Alexander in Religion in England, 1558-1662 (London: University of London Press, 1968), p. 75.

35. Gutierrez, p. 186.

36. The citation is from The N-Town Play, Cotton MS Vespasian D.8, vol. 1, ed. Stephen Spector (Oxford: Oxford University Press for The Early English Text Society, 1991).

37. See Jeffrey, p. 72.

38. For a fine discussion of this matter see John L. Klause, "Donne and the Wonderful," English Literary Renaissance 17 (1987): 41-66, esp. 56-57.

39. Davidson, "The Devil's Guts," p. 107.

40. Diehl, 159. Eamon Duffy, "Mary," in The Impact of the English Reformation, 1500-1640, ed. Marshall, pp. 225-26, shows how even in queen Mary's reign, the Reformers' campaign against Mariolatry and affective images had been so successful that the images of the Virgin offered to a sensitized populace had narrowed.

41. Elizabethan Homilies (1623), 2 vols. [1547, 1571], Old-Spelling Edition of Short Title Catalog \#13675, general ed. Ian Lancashire (Toronto: University of Toronto Library, 1997), 2: 2.3.1732-34. On the proclamation requiring the regular reading of the homilies in church, see Tudor Royal Proclamations, 2: 133.

42. I adapt this idea from Margaret Aston, England's Iconoclasts, vol. 1, Laws Against Images (Oxford: Clarendon Press, 1988), p. 401, who treats full-standing statues as actors.

43. Diehl, p. 164.

44. Frances E. Dolan, Whores of Babylon: Catholicism, Gender, and Seventeenth-Century Print Culture (Ithaca, NY: Cornell University Press, 1999), p. 8.

45. The phrases are from Marjorie M. Malvern, Venus in Sackcloth: The Magdalene's Origins and Metamorphoses (Carbondale: Southern Illinois University Press, 1975), pp. 13, 84. On Mary Magdalene and her cult, see Susan Haskins, Mary Magdalen, Myth and Metaphor 
(New York: Harcourt Brace, 1993); Katherine Ludwig Jansen, The Making of the Magdalen: Preaching and Popular Devotion in the Later Middle Ages (Princeton, NJ: Princeton University Press, 2000); and Laura Severt King, "Blessed when they were riggish: Shakespeare's Cleopatra and Christianity's Penitent Prostitutes," Journal of Medieval and Renaissance Studies 22 (1992): 429-49.

46. See Debora Kuller Shuger's account of this process in The Renaissance Bible: Scholarship, Sacrifice, and Subjectivity (Berkeley: University of California Press, 1994), p. 178.

47. Examples abound. The York Slaughter of the Innocents (fourteenth century) shows Herod repeatedly tying himself to "allmyghty Mahounde" $(1.15 ; c f .11 .19,35,73)$, and the Digby Mary Magdalen (c. 1480-1520) has him swear "by Mahondys bonys," declaring himself a disciple and "trew kyng to Mahond so fre!" (11. 142-43). Citations are from The York Plays, ed. Richard Beadle (London: Edward Arnold, 1982), and The Late Medieval Religious Plays of Bodleian MSS Digby 133 and E Museo 160 (includes Mary Magdalen), ed. Donald C. Baker, John L. Murphy, and Louis B. Hall, Jr. (Oxford: Oxford University Press for the Early English Text Society, 1982). Subsequent citations of these works are referenced in the body of my text.

48. See Julia Gasper, The Dragon and the Dove: The Plays of Thomas Dekker (Oxford: Clarendon Press, 1990), p. 68, and Samuel C. Chew's magisterial examination, The Crescent and the Rose: Islam and England during the Renaissance (1937; rpt. New York: Octagon Books, 1965), pp. 397-400.

49. On Mohammed and the dove, see Chew, p. 406; $c f$. Andrew S. Cairncross, ed., The First Part of King Henry VI (London: Methuen; Cambridge, MA: Harvard University Press, 1962), p. 20n.

50. See Michael Hattaway, ed., The First Part of King Henry VI, (Cambridge: Cambridge University Press, 1990), p. 82n. Pertinently, the popular "Homily Against Peril of Idolatry" recites every manner of the pagan worship of Venus, condemning them all (Elizabethan Homilies, 2: 2.3.1621-54).

51. Hattaway, ed., 1 Henry VI, p. 96n.

52. Cited by Frances Gies, Joan of Arc: The Legend and the Reality (New York: Harper \& Row, 1981), p. 236.

53. Throughout the paragraph, I cite from Edward Hall, The Vnion of the Two Noble and Illustre Famelies of Lancastre \& Yorke, 1548, rpt. as Hall's Chronicle; Containing the History of England (1809; rpt. New York: AMS Press, 1965), pp. 157-59. I have expanded Hall's abbreviations while preserving the old-spelling of his text.

54. Richard Hillman, Shakespeare, Marlowe and the Politics of France (Basingstoke and New York: Palgrave, 2002), p. 139; $c f$. p. 150.

55. Le Mistère du siège d'Orléans, ed. F. Guessard and E. De Certain (Paris, 1862), pp. i-vii.

56. Fronton Du Duc, L'histoire tragique de la Pucelle de Dom-Rémy, ed. Marc André Prévost, in La tragédie à l'époque d'Henri III, vol. 2 of Théâtre français de la Renaissance, 2nd series (Florence: Leo S. Olschki; Paris: Presses Universitaires de France, 2000), pp. 280-81. Citations of the play refer to this edition. See also the edition entitled L'Histoire tragique de la pucelle d'Orléans, ed. Durand de Lançon (1859; fac. rpt. Geneva: Slatkine Reprints, 1970).

57. Hillman, p. 139.

58. Hillman, pp. 143-44, draws attention to these elements. See his penetrating account of Du Duc's play in relation to Shakespeare and the politics of France (pp. 140-52). 
30 / Renaissance and Reformation / Renaissance et Réforme

59. In addition to Marcus, pp. 84-85, see the parallels with Elizabeth adduced by Barbara Hodgdon, The End Crowns All: Closure and Contradiction in Shakespeare's History (Princeton, NJ: Princeton University Press, 1991), pp. 54-59, and John N. King, Tudor Royal Iconography: Literature and Art in an Age of Religious Crisis (Princeton, NJ: Princeton University Press, 1989), who observes that Elizabeth acquired the epithets of Virgin, Bride, Mother, and Queen "as part of an effort to channel traditional [Mariological] devotional forms in support of her regime" (p. 203).

60. Jansen, pp. 35-39.

61. Eamon Duffy, The Stripping of the Altars: Traditional Religion in England, c. 1400-c. 1580 (New Haven, CT: Yale University Press, 1992), pp. 430, 394-95.

62. Laura Severt King, pp. 439-41.

63. Haskins, pp. 248-51, discusses in particular Calvin's and Zwingli's strictures against the cult of the Magdalene. For an account of how the Magdalene's legend grew, see Jansen, pp. 18-46.

64. Morris Palmer Tilley, A Dictionary of The Proverbs in England in the Sixteenth and Seventeenth Centuries (Ann Arbor: University of Michigan Press, 1966), pp. 241-42; James C. Bryant, Tudor Drama and Religious Controversy ([Macon, GA]: Mercer University Press, 1984), pp. 116-24.

65. Tudor Royal Proclamations, 2: 123.

66. Jansen, p. 42.

67. Elizabethan Homilies, "Homily Against Peril of Idolatry," 2: 2.1.62-63, 27-28, 56-58.

68. "The Tridentine Profession of Faith," in Documents of the Christian Church, ed. Bettenson, pp. 374-75.

69. See John Bossy, "The English Catholic Community 1603-1625," in The Reign of James VI and I, ed. Alan G. R. Smith (London: Macmillan, 1973), pp. 101-2, and Dolan, pp. 18-23. However, we need not assume that English Catholics necessarily embraced old-faith practices that were reconstituted as idolatrous.

70. The citation is from Eggert, p. 67. Others taking this view include A. L. French, "Joan of Arc and Henry VI," English Studies 49 (1968): 427, and Frederick S. Boas, "Joan of Arc in Shakespeare, Schiller, and Shaw," Shakespeare Quarterly 2 (1951): 39.

71. Tudor Royal Proclamations, 2: 126; see also Keith Thomas, Religion and the Decline of Magic (New York: Charles Scribner's Sons, 1971), pp. 253-57.

72. Alan Macfarlane, Witchcraft in Tudor and Stuart England, A Regional and Comparative Study (London: Routledge \& Kegan Paul, 1970), pp. 14-15.

73. Lewis Wager, The Life and Repentaunce of Marie Magdalene, ed. Frederic Carpenter (Chicago: University of Chicago Press, 1902).

74. In describing Joan in relation to Mary Magdalene as an "abandoned woman," I allude to Lawrence Lipking's Abandoned Women and Poetic Tradition (Chicago: University of Chicago Press, 1988).

75. Geneva Bible: A Facsimile of the 1560 Edition, introduction by Lloyd E. Berry (Madison: University of Wisconsin Press, 1969), Luke 1:42.

76. Lynette R. Muir, “The Saint Play in Medieval France," in The Saint Play in Medieval Europe, ed. Davidson, pp. 136-37, offers a rare, albeit brief, discussion of Le Mistère.

77. Levine, p. 43. See also Jackson, pp. 60-64. 
Albert H. Tricomi / Joan la Pucelle and the Inverted Saints Play / 31

78. Marcus, pp. $87-88$.

79. Levine, p. 43.

80. Peter Happé, English Drama Before Shakespeare (London: Longman, 1999), p. 102; Warren W. Wooden, John Foxe (Boston: Twayne, 1983), pp. 12-13.

81. John King, p. 207.

82. Foxe, 5: 537-53.

83. Ibid., 5: 548 .

84. Ibid., 5: 455. See Ritchie D. Kendall, The Drama of Dissent: The Radical Poetics of Non-conformity, 1380-1590 (Chapel Hill: University of North Carolina Press, 1986), p. 127.

85. Foxe, 5: 455. 